\title{
Luxury Strategy by Daily Fashion Brand of UNIQLO: Flagship Shop Strategy for Large Store Location
}

\author{
Shin'ya Nagasawa ${ }^{1 *}$ and Norihiro Suganami ${ }^{2}$ \\ ${ }^{1}$ Waseda University, Japan \\ ${ }^{2}$ Tanseisha Co. Ltd., Japan
}

*Corresponding author: Shin'ya Nagasawa, Professor, Graduate School of Business and Finance, Waseda University, Tokyo, Japan.

\section{Abstract}

Most of the luxury brands have flagship shops. In recent years, daily fashion brands and fast fashion brands also have flagship shops. Both flagship shops are large store, located in special place such as Ginza for brand-building. However, flagship shop importance is not only place and size but also Product, Price, Promotion. In this article, we investigate flagship shop strategy and the relationship between flagship shop strategy and brand building by case UNIQLO.

Keywords: UNIQLO; Daily fashion brand; Large store location; Flagship shop strategy

\section{Introduction}

As Japanese retailers struggle to expand overseas, UNIQLO has been achieving success in overseas expansion with the opening of flagship shops. This is surprisingly the same as how European and American luxury brands, which are on the opposite end of the spectrum from daily fashion retailer UNIQLO, expanded in Japan by opening flagship shops. This means that the flagship shop strategy is similarly being adopted by Western luxury brands [1-3] that are polar opposites from UNIQLO, which is a daily fashion retailer [4]. Yet, does the fact that such companies are not only focusing on advertisements and promotions, but also spending a large amount of capital to open flagship shops, mean that flagship shops are taking on an aspect of brand building that cannot be achieved through advertisement and promotions alone?

To answer that, this paper seeks to systematize the flagship shop strategy by comparatively analyzing cases in the overseas expansion of Fast Retailing Co., Ltd. in which their subsidiary UNIQLO failed with normal stores but succeeded with flagship shops. This paper also elucidates the casual relationship between the flagship shop strategy and brand building by investigating why success can only be achieved with flagship shops, but not with normal stores.

In the next Section, previous studies on flagship shops are reviewed and the analytical framework for this paper is presented.
Section 3 introduces an overview of UNIQLO, Section 4 analyzes UNIQLO's successes and failures in overseas expansion, Section 5 analyzes UNIQLO's flagship shop strategy, in Section 6 flagship shops are systematized, and Section 7 discusses flagship shop strategies and brand building. Finally, verification is performed using the results from fieldwork conducted at the New York Fifth Avenue store.

\section{Previous Studies on Flagship Shops}

This section outlines previous studies on flagship shops and explains this paper's position. In previous studies, flagship shops are defined as follows. Although fashion related books tend to describe flagship stores (flagship shops) as "stores that carry all of a brand's products," [5,6] we have defined flagship shops as "stores that carry all of a brand's products while exhibiting the brand's essence [7]".

Despite there being definitions for flagship shops, there are currently no in-depth discussions in Japan on flagship shops since they are seen as a part of an overall business strategy.

Even in Flagship Marketing [8-10], no research covering Japanese companies had been conducted on flagship shop strategies and brand building. 
This paper therefore takes up the case of a Japanese company, systematizes their flagship shop strategy, and analyzes the use of the flagship shop strategy for brand building [11].

\section{Overview of Fast Retailing Co., Ltd}

Fast Retailing Co., Ltd. was founded in Yamaguchi Prefecture in 1963. The first UNIQLO casual-wear retail store opened in Hiroshima in 1984, and Tadashi Yanai was appointed president in the same year. The company became listed on the Hiroshima Stock Exchange in 1994, and then in the second section of the Tokyo Stock Exchange in 1997. The scale of their business expanded with fleece becoming a hot trend in 1998, and they became listed in the first section of the Tokyo Stock Exchange in 1999. After a subsequent period of decreased revenue and profits, business recovered, being spurred by an increase in women's products, and with consolidated sales of 2,290.5 billion yen and operating profits of 257.6 billion yen in 2019 , they came to represent one of Japan's top companies.

Fast Retailing's business is divided into the four segments of UNIQLO Japan operations, Japan-related business operations, UNIQLO international operations, and global brand operations.

This paper only covers the UNIQLO international operations segment. The UNIQLO international operations segment was founded with the company's expansion to UK in 2001, and by 2019 they had developed their overseas presence to 1379 stores throughout China (717 stores), Hong Kong (29 stores), Korea (188 stores), the United States (51 stores), France (24 stores), Singapore (28 stores), Russia (37 stores) and so on, while 817 stores in Japan. Initially international operations struggled, but they have been producing profits since 2008, and sales for the year ending in August 2019 were 1,026.0 billion yen (in Japan 872.9 billion yen), while operating profits were 138.9 billion yen (in Japan 102.4 billion yen) [12].

Although the sales ratio is currently $54.0 \%$, this is a segment for which growth can be thoroughly anticipated for in the future.

\section{UNIQLO's Overseas Expansion}

\section{UNIQLO's overseas expansion failure - UK case}

UNIQLO's overseas expansion started with their expansion to UK in 2001. Under a strategy to open 50 stores within three years and to also produce profits within three years, they opened four stores in London, with the Knightsbridge store (198 tsubo, equivalent to approximately $655 \mathrm{~m}^{2}$ ), the Wimbledon store (177.5 tsubo, equivalent to approximately $587 \mathrm{~m}^{2}$ ), the Romford store (191 tsubo, equivalent to approximately $631 \mathrm{~m}^{2}$ ), and the Uxbridge store (174.5 tsubo, equivalent to approximately $577 \mathrm{~m}^{2}$ ). By 2002, they had expanded to 21 stores, but due to having 360 million yen in losses, it was announced that 16 stores would be closed down in 2003. UNIQLO's expansion in UK had failed.

As President Yanai subsequently remarked regarding the failure in UK that "There is absolutely no familiarity with UNIQLO (overseas). You can't expect a brand to sell if people don't know it. This was not a matter of good or bad products, the problem was one step before," $[13,14]$ their overseas expansion failure can be attributed to the low degree of familiarity with the brand. However, it is thought that there must have been a degree of familiarity with UNIQLO in London, considering that at the time of the expansion in 2001, UNIQLO was promoted extensively using advertisements on buses that ran through London and so forth, and considering that the Knightsbridge store was in a prime location where the luxury department store Harrods is also located. UNIQLO's failure in UK was not simply a problem of consumers being unfamiliar with the brand. Since the failure occurred even at the Knightsbridge store, where extensive promotions were carried out, it is thought that the cause was a complex intertwining of operational problems in which UNIQLO's characteristic features were diminished due to British personnel being appointed to manage the subsidiary, and the problem of being unable to achieve brand awareness based on promotions and location alone.

\section{UNIQLO's overseas expansion success - US Case}

In the United States, three stores were opened in September of 2005 in shopping centers in the New Jersey suburbs, with the Menlo Park Mall store (217 tsubo, equivalent to approximately 717 $\mathrm{m}^{2}$ ), the Rockaway Townsquare store (151 tsubo, equivalent to approximately $499 \mathrm{~m}^{2}$ ), and the Freehold Raceway Mall store (223 tsubo, equivalent to approximately $737 \mathrm{~m}^{2}$ ). The failures in UK were taken into account and the company employed a strategy in which they moved forward while using the stores as test stores to study the market, but sluggish sales persisted. However, when inventory that was not selling started to be stockpiled and a provisional 80-tsubo (equivalent to approximately $265 \mathrm{~m}^{2}$ ) sized store in Soho was opened to help get rid of that inventory, sales ended up being higher than the three New Jersey stores. As a result, the opening of a large-scale store in Soho was considered, and after conducting extensive promotions, the Soho New York store was opened as a flagship shop in November of 2006. Being located on Broadway, it became a hot topic amongst many local media outlets, and sales have steadily achieved targets since the opening (Figure 1).

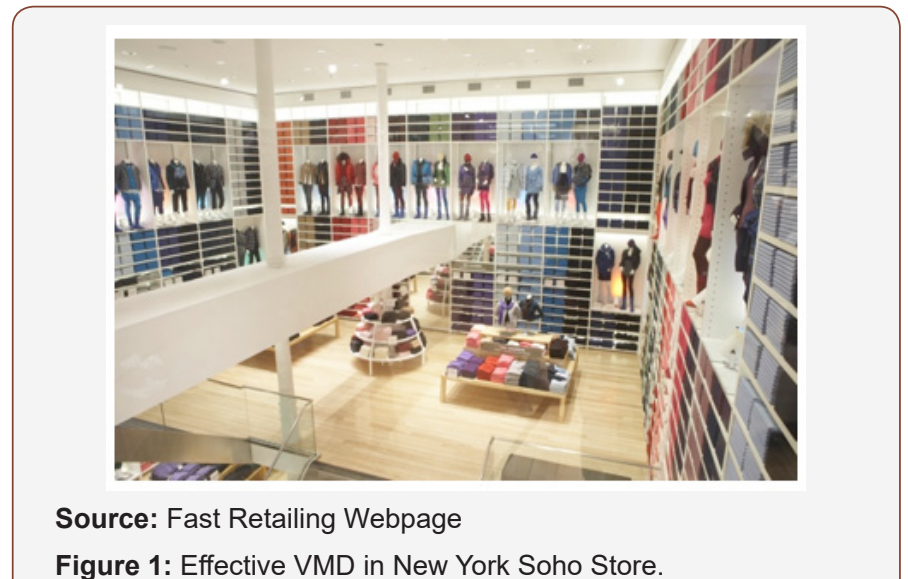

Figure 1: Effective VMD in New York Soho Store.

After the flagship shop success of the Soho New York store, Fast Retailing's 2006 annual report expresses a keen realization of the vital importance of brand awareness in order to succeed in overseas expansion, and indicates a shift in strategy to rapidly increase familiarity with the brand by opening a flagship store 
wherever the center for fashion is located in the region in question. It can be said that instead of heightening familiarity by gradually increasing the number of standard-sized stores, as had been done until then, UNIQLO switched to a brand-building strategy in which flagship shops are used to instantly increase familiarity.

Thereafter, UNIQLO developed their overseas presence using flagship shops as a springboard, with the Shanghai Global Flagship Store (700 tsubo, equivalent to approximately $2314 \mathrm{~m}^{2}$ ) opening in December of 2006, the Oxford Street store (700 tsubo, equivalent to approximately $2314 \mathrm{~m}^{2}$ ) opening in November of 2007, the Seoul Myeongdong store (700 tsubo, equivalent to approximately 2314 $\mathrm{m}^{2}$ ) opening in December of 2007, the Paris Opera store (650 tsubo, equivalent to approximately 2,149 $\mathrm{m}^{2}$ ) opening in October of 2009 , the Shanghai West Nanjing Road store opening in May of 2010, and the New York Fifth Avenue store opening in October of 2011. The company's international operations which had continually produced deficits since 2001, started turning out profits from FY $2008[15,16]$.

\section{UNIQLO Flagship Shop 4Ps Analysis}

A The cases of failure with the three stores (normal stores) in the New Jersey shopping centers and the case of success with the Soho, New York store which was opened as a flagship shop were compared using a 4Ps analysis, as shown in Table 1 below.

Table 1: UNIQLO Flagship Shop 4Ps Analysis.

\begin{tabular}{|c|c|c|}
\hline & $\begin{array}{l}3 \text { New Jersey Stores } \\
\text { (Normal Stores) }\end{array}$ & $\begin{array}{l}\text { Soho New York Store } \\
\text { (Flagship shop) }\end{array}$ \\
\hline \multirow[t]{3}{*}{ Product } & \multirow{3}{*}{$\begin{array}{l}\text { Primarily menswear and ladies wear were put out } \\
\text { (limited-stock items and innerwear not put out) }\end{array}$} & $\begin{array}{l}\text { - Assortment of all products including menswear, ladies } \\
\text { wear, innerwear, etc. }\end{array}$ \\
\hline & & $\begin{array}{l}\text { - Overwhelming product quantity (great quantities of } \\
\text { the same product put out) }\end{array}$ \\
\hline & & $\begin{array}{l}\text { - Limited-stock items offered (T-shirts by Japanese art- } \\
\text { ists, etc.) }\end{array}$ \\
\hline \multirow[t]{2}{*}{ Price } & \multirow[b]{2}{*}{ - $\quad$ Low price range (daily fashion price range) } & - $\quad$ Low price range (daily fashion price range) \\
\hline & & $\begin{array}{l}\text { - Price range broadened through more varied product } \\
\text { mix }\end{array}$ \\
\hline \multirow{3}{*}{$\begin{array}{l}\text { Place (Distribu- } \\
\text { tion } \rightarrow \text { Location/ } \\
\quad \text { Store) }\end{array}$} & $\begin{array}{l}\text { - Stores located in ordinary areas (inside of suburban } \\
\text { shopping centers), based on premise of regular, } \\
\text { everyday consumption }\end{array}$ & $\begin{array}{l}\text { - Stores located in fashion district, and globally re- } \\
\text { nowned location (Manhattan's Soho district) }\end{array}$ \\
\hline & $\begin{array}{l}\text { - } \quad \text { Standard-sized stores (151-223 tsubo, equivalent to } \\
\text { approximately } 499-737 \mathrm{~m}^{2} \text { ) }\end{array}$ & $\begin{array}{l}\text { - Megastore (1000 tsubo equivalent to approximately } \\
3305 \mathrm{~m}^{2} \text { ) }\end{array}$ \\
\hline & $\begin{array}{l}\text { - Limited VMD (primarily half-body torso manne- } \\
\text { quins, clothing racks, and hanger displays) }\end{array}$ & $\begin{array}{l}\text { - } \quad \text { Measures taken to promote Japan (appointing famous } \\
\text { Japanese creative artists, etc.) }\end{array}$ \\
\hline \multirow[t]{2}{*}{ Promotion } & \multirow[t]{2}{*}{ - Nonlarge-scale promotions } & $\begin{array}{l}\text { - Extensive promotions (original CDs, container shops, } \\
\text { etc.) }\end{array}$ \\
\hline & & - $\quad$ Publicity \\
\hline
\end{tabular}

\section{Products}

In the product category, the flagship shop has an assortment of all of the products UNIQLO carries, from menswear and ladies wear, to baby products, innerwear, and accessories, etc. In the normal stores the variety and number of products offered is limited, yet the flagship shop carries all products and displays them in large volumes, enabling the flagship shop to convey the UNIQLO brand, even to customers who are not familiar with UNIQLO. To present eye-catching goods, a T-shirt project was launched with the collaboration of 34 artists representing Japan, which not only provided incentives at the grand opening and gave the impression of UNIQLO being a store that carries basic items, but also worked to convey UNIQLO's Japanese nature and the fact that they carry fashion-minded elements.

\section{Price}

Regarding price, the same product prices are offered as the normal stores, but as the product mix is increasingly varied, there is a broadened price range from the product prices offered at the normal stores.
Place

Regarding place (location), the flagship shop was opened in the Soho district, which even in New York is considered to be particularly highly receptive to fashion. Many luxury brands, such as Louis Vuitton, as well as many fast fashion brands, such as H\&M, have stores in Soho. By opening a store in an area that is highly receptive to fashion and that also garners a lot of attention, it was possible to increase both cognizance of UNIQLO as a fashion brand and their brand image.

Regarding place (store), Japan's top creative artists were brought in, with Kashiwa Sato appointed as creative director and Masamichi Katayama appointed as interior designer. UNIQLO's previous logo was changed to a logo in two scripts, English and Japanese, and the store was designed based on the concept of "Modern Japan," using a primarily white palette to express the themes of Japanese minimalism, cutting-edge Japan, and "Cool Japan."

It is thought that the brand value of Japan and "Cool Japan" were added to the UNIQLO brand as a result of those themes being represented in the store. Also, while the normal stores have limited 
space for VMD, there is significant VMD space in the flagship shop, and with expansive flat display cases and the use of many full-body mannequins offering a distinctive touch, the flagship shop serves as a mechanism for deeply impressing UNIQLO brand image upon customers who are not familiar with UNIQLO. Regarding store area, the flagship store is a 1000-tsubo (equivalent to approximately $3306 \mathrm{~m}^{2}$ ) sized megastore that is approximately five times the size of regular stores.

Considering that it is a place where the brand image is conveyed by means of all of the brand's products being displayed, a certain amount of space is required.

\section{Promotion}

Regarding promotion, familiarity with UNIQLO was increased and the extent of brand awareness was broadened before the grand opening by launching extensive promotions, such as selling a UNIQLO original CD titled "SYNCHRO / FROM TOKYO TO NEW YORK" containing songs selected by representative Japanese DJ, Tomoyuki Tanaka, conducting pre-sales from September, two months before the grand opening, using container shops that popped up at various locations throughout Manhattan, distributing a free magazine called the "UNIQLO Paper" in which one of New York's top art directors, Markus Kiersztan, served as chief editor and which contained contributions from top creative artists, and streaming the Soho shop online in real time from the opening.

As a result, the line of customers waiting to get in at the grand opening of the Soho New York store as a flagship shop in November of 2006was covered extensively in the media, brand awareness was further broadened due to the publicity, and success was achieved in deepening brand association.

\section{Flagship Shop Strategy Systematization}

Although the flagship shop strategy of not just one case, but of multiple brands, must be studied from here, we systematized the flagship shop strategy by drawing correlations from the 4Ps analysis of the UNIQLO flagship shop, as shown in Figure 2 below.

The objective and resultant effect is that by opening a flagship shop in a state in which there is no familiarity with the brand, brand awareness can be rapidly increased and brand association can be deepened.

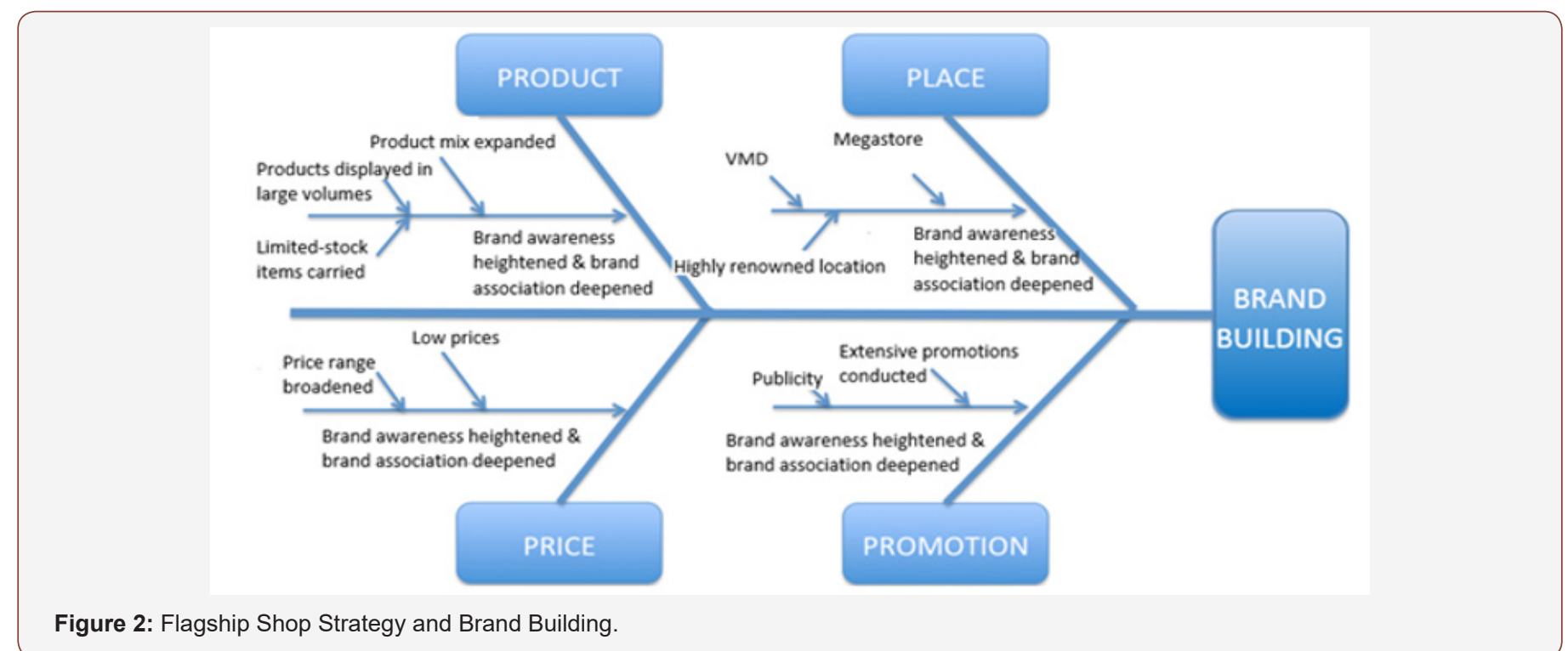

\section{Products}

In the product category, all of the products carried by the company are offered to convey the brand to unfamiliar customers. The sale of limited-stock items also helps to convey the brand image that serves as the brand's distinctive characteristic, and it also provides incentives at the grand opening.

\section{Price}

Regarding price, prices for the same products are not made cheaper or more expensive on the grounds that they are being sold at the flagship shop, yet because the product mix is more varied, there is a broader price range than at the normal stores. Also, the broadening of the price range enables the scope of their brand image to also be broadened.

\section{Place}

Regarding place (location), the store is opened in a renowned location in the country in question. Opening the flagship shop in a location that is highly receptive to fashion broadens and deepens awareness of the brand as a fashion brand.

Regarding place (store), the sales floor area is a suitable size for carrying all of the brand's products, and the store area must ensure that there is space for VMD in order to convey the brand. Therefore, it is inevitably a large-scale store. Mechanisms are also created for collaborating with famous creative artists and conveying the brand's country of origin, and that country's value is added to the brand value.

\section{Promotion}

Regarding promotion, brand awareness is not only deepened through extensive promotions, but the grand opening also gets covered by the media and in aiming for publicity, brand association is strengthened, and the brand image is improved. 
In the next section, the correlations are discussed in the context of brand building.

\section{Flagship Shop Strategy and Brand Building}

It has been said regarding sources of brand equity that "Establishing a positive brand image in consumer memory-strong, favorable, and unique brand associations-goes hand-in-hand with creating brand awareness" [17-20]. In other words, brand building is achieved through strengthening consumers' brand awareness and brand association. We verify how the flagship shop strategy can heighten brand awareness and strengthen brand association based on the 4P analysis for UNIQLO's flagship shop strategy.

As shown in Figure 2, consumers' brand awareness is increased through promotion and place (location) which leads to consumers visiting the store. Moreover, product, price, and place (store) all work to heighten consumers' brand awareness and strengthen brand association at the store, where consumers actually come into contact with the brand. Based on these factors, it can be said that the flagship shop strategy, as shown in Figure 2, contributes to brand building as product, price, place (location and store), and promotion all work to heighten brand awareness and strengthen brand association.

\section{Verification: New York Fifth Avenue Global Flagship Store}

We conducted fieldwork at the New York Fifth Avenue Global Flagship Store, which opened on 14 October 2011, and verified the flagship shop strategy discussed heretofore through a 4Ps analysis of the flagship shop strategy at the Fifth Avenue store and the Soho New York store, which opened five years earlier, as shown in Table 2 below.

Table 2: 4Ps Analysis for NY Soho Store and NY Fifth Avenue Store.

\begin{tabular}{|c|c|c|}
\hline & Soho New York Store (Flagship Shop) & $\begin{array}{l}\text { Fifth Avenue Store } \\
\text { (Flagship Shop) }\end{array}$ \\
\hline \multirow{4}{*}{ Product } & $\begin{array}{l}\text { - Assortment of all products including menswear, } \\
\text { ladies wear, innerwear, etc. }\end{array}$ & $\begin{array}{l}\text { - Assortment of all products including menswear, ladies } \\
\text { wear, innerwear, etc. }\end{array}$ \\
\hline & $\begin{array}{l}\text { - Overwhelming product quantity (great quantities } \\
\text { of the same product put out) }\end{array}$ & $\begin{array}{l}\text { - Overwhelming product quantity (great quantities of } \\
\text { the same product put out) }\end{array}$ \\
\hline & \multirow{2}{*}{$\begin{array}{l}\text { - } \quad \text { Limited-stock items offered (T-shirts by Japanese } \\
\text { artists, etc.) }\end{array}$} & $\begin{array}{l}\text { - Limited-stock items offered (Japanese anime, MOMAT } \\
\text { shirts) }\end{array}$ \\
\hline & & - $\quad$ Products with limited-time prices offered $\rightarrow$ Price \\
\hline \multirow{3}{*}{ Price } & - $\quad$ Low price range (daily fashion price range) & - $\quad$ Low price range (daily fashion price range) \\
\hline & \multirow{2}{*}{$\begin{array}{l}\text { - Price range broadened through more varied prod- } \\
\text { uct mix }\end{array}$} & $\begin{array}{l}\text { - Price range broadened through more varied product } \\
\text { mix }\end{array}$ \\
\hline & & $\begin{array}{l}\text { - Limited-time prices, eye-catching prices (jeans for } \\
\$ 9.99 \text {, etc.) }\end{array}$ \\
\hline \multirow{3}{*}{$\begin{array}{l}\text { Place (Distribu- } \\
\text { tion } \rightarrow \text { Location/ } \\
\quad \text { Store) }\end{array}$} & $\begin{array}{l}\text { - Fashion district, and globally renowned location } \\
\text { (Manhattan's Soho district) }\end{array}$ & $\begin{array}{l}\text { - Globally renowned location where the street is lined } \\
\text { luxury brand shops (Manhattan's Fifth Avenue) This is } \\
\text { a location that not only the wealthy classes, but people } \\
\text { from all classes visit, with many tourists and visitors } \\
\text { from all over the world }\end{array}$ \\
\hline & $\begin{array}{c}\text { - Megastore (1000 tsubo equivalent to approximate- } \\
\text { ly } 3305 \mathrm{~m}^{2} \text { ) }\end{array}$ & $\begin{array}{l}\text { - Megastore (1500 tsubo equivalent to approximately } \\
4959 \mathrm{~m}^{2} \text { ) }\end{array}$ \\
\hline & $\begin{array}{l}\text { - Measures taken to promote Japan (appointing fa- } \\
\text { mous Japanese creative artists, etc.) }\end{array}$ & $\begin{array}{l}\text { - } \quad \text { Measures taken to promote Japan (appointing famous } \\
\text { Japanese creative artists, etc.) }\end{array}$ \\
\hline \multirow[t]{2}{*}{ Promotion } & $\begin{array}{l}\text { - Extensive promotions (original CDs, container } \\
\text { shops, etc.) }\end{array}$ & $\begin{array}{l}\text { Extensive promotions (advertising on public transpor- } \\
\text { tation (subways, buses, taxis), container shops, flyers, } \\
\text { handing out tissue packs, newspaper advertisements, } \\
\text { online advertising) }\end{array}$ \\
\hline & - $\quad$ Publicity & $\begin{array}{l}\text { - Publicity (global strategy announcements, grand open- } \\
\text { ing announcements) }\end{array}$ \\
\hline
\end{tabular}

The flagship shop strategies of the Soho New York store and the Fifth Avenue store were found to be similar, and the results of our fieldwork suggested a certain degree of validity for the flagship shop strategy that we systematized based on the Soho New York in Section 6 store.

At the grand opening, UNIQLO announced plans to open 300 stores overseas over the span of a year, and to also open 1,600 stores in the United States, which is double the number of stores in Japan. To do so, they are expanding and intensifying the flagship shop strategy beyond that of the previous Soho New York store. In the price category, since there is already a flagship store in New York, the Fifth Avenue store is devising mechanisms that ensure customers visit the store, such as introducing jeans for $\$ 9.99$. Many of the customers visiting the store did in fact come with the intention of purchasing jeans for $\$ 9.99$, and many ended up purchasing multiple pairs. Regarding place, since Fifth Avenue is a location that not only tourists from all over the United States, but from all over the world visit, opening a store on Fifth Avenue makes it possible to make UNIQLO known both throughout the United States and throughout the world. Furthermore, with a 1500-tsubo 
(equivalent to approximately $4959 \mathrm{~m}^{2}$ ) sized megastore which outdoes all of the other daily fashion retailers, not only does the sheer magnitude of the store draw attention while the rich VMD and monitors help to build awareness of the UNIQLO brand inside of the store, but such mechanisms also facilitate deep penetration. Regarding promotion, publicity was achieved through efforts such as filling public transportation advertising space throughout Manhattan with UNIQLO advertisements and inviting New York mayor Michael Bloomberg to the grand opening ceremony. As can be seen in Figure 3, many media outlets came to cover the grand opening, and the UNIQLO opening was widely reported, including in Japan.

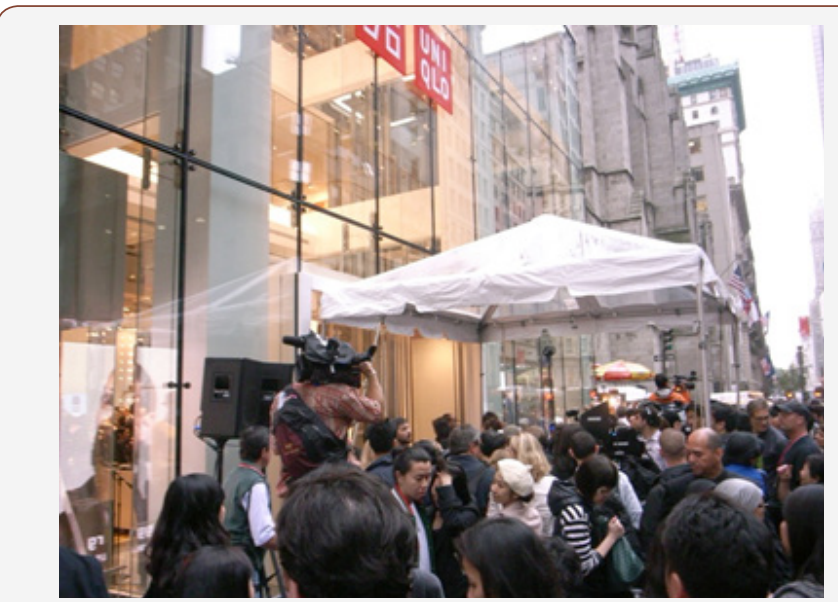

Figure 3: Fifth Avenue Store Grand Opening.

\section{Conclusion}

In overseas markets that serve as new markets, it is important to not just make the brand known exclusively through advertising and promotions, but to build consumers' brand awareness regarding the brand's prices and quality, etc., and to strengthen brand association in order to achieve actual purchasing, since most of the consumers there have no experience with the brand. This is precisely why it is thought that UNIQLO is adopting a flagship shop strategy, and not a strategy which depends on advertisements and promotions alone.

Since flagship shops are stores, generally speaking one could consider only the place (location/distribution) element involved in a 4Ps analysis, but it can be said that the differences between a normal store strategy and a flagship shop strategy are not simply location and distribution. Each element of the 4Ps, product, price, place (location and store), and promotion, is different between the two types of shops, and each element plays a role in establishing brand awareness and strengthening brand association.

It is important for flagship shop strategies to contribute to strong brand building by incorporating all of these elements into the marketing mix [21].

\section{Acknowledgement}

This paper is financially supported by Grant-in-Aid (B) No. 18H00908 of Japan Society for the Promotion of Science (JSPS).

\section{Conflict of Interest}

Authors declare no conflict of interest.

\section{References}

1. Nagasawa S (2016) Japan Has Developed Luxury Brands. Marketing Review St. Gallen 33(5): 58-67.

2. Nagasawa S (2019) On the Future of Fetish/ Affective Value. Journal of Textile Science \& Fashion Technology 3(3): 1-4.

3. Kumagai K, Nagasawa S (2015) Observations of luxury brand's perceived position and their key success factor (L-KSF) in the Japanese market. Transaction of Japan Society of Kansei Engineering 14(2): 257-268.

4. Kumagai K, Nagasawa S (2016) The influence of social self-congruity on Japanese consumers' luxury and non-luxury apparel brand attitudes. Luxury Research Journal 1(2): 128-149.

5. Japan Association for Promotion of Fashion Education (1996) Fashion Brand Strategy, Japan Association for Promotion of Fashion Education, Tokyo, Japan.

6. Japan Association for Promotion of Fashion Education (2008) Fashion Business [I], Japan Association for Promotion of Fashion Education, Tokyo, Japan.

7. Nagasawa S (2009) Premium Strategy of Local and Traditional Industries of Japan: Building Customer Experience and Technology Management, Doyukan, Tokyo, Japan.

8. Kozinetsa RV, Sherrya JF, DeBerry-Spencea B, Duhacheka A, Nuttavuthisita K, et al. (2002) Themed flagship brand stores in the new millennium: theory, practice, prospects. Journal of Retailing 78(1): 1729.

9. Kent T, Brown R (2009) Flagship Marketing: Concepts and Places, Routledge, London, UK.

10. Moore CM, Doherty AM, Doyle SA (2010) Flagship stores as a market entry method: the perspective of luxury as a market entry fashion retailing". European Journal of Marketing 44(1/2): 139-161.

11. Nagasawa S, Suganami N (2018) Flagship Shop Strategy for Brand Building: Case of UNIQLO. Proceedings of 2018 Global Marketing Conference at Tokyo: 1144-1156.

12. Fast Retailing Co., Ltd. (2019) Annual Report 2000-2019.

13. Yanai T (2004) Issho Kyuhai (One Win Nine Losses). Shincho-sha Publishing Co., Ltd, Tokyo, Japan.

14. Yanai T (2009) Seiko Wa Ichinichi De Sutesare (Forget about Success in One Day). Shincho-sha Publishing Co., Ltd, Tokyo, Japan.

15. Matsushita K (2010) Yunikuro No Shinkaron (Evolution Theory for UNIQLO). Business-sha, Inc, Japan.

16. Saito T (2018) UNIQLO vs AZRA, Nihon Keizai Shimbun-sha, Tokyo, Japan.

17. Keller KL (2007) Strategic Brand Management 3rd ed., Prentice Hall, New Jersey, USA.

18. Kapferer JN (1998) Why are we seduced by luxury brands? Journal of Brand Management 6(1): 44-49.

19. Kapferer JN, Bastien V (2012) The luxury strategy (2nd edn): Break the rules of marketing to build luxury brands, Kogan Page Limited, London.

20. Kapferer JN (2015) Kapferer on Luxury: How Luxury Brands Can Grow Yet Remain Rare, Kogan Page, London.

21. Nagasawa S, Suganami N (2018) Flagship Shop Strategy for Brand Building: Case of UNIQLO. Proceedings of 2018 Global Marketing Conference at Tokyo: 1144-1156. 